\title{
Transcription Initiation Factor IIE Subunit Beta
}

National Cancer Institute

\section{Source}

National Cancer Institute. Transcription Initiation Factor IIE Subunit Beta. NCI Thesaurus. Code C29686.

Transcription initiation factor IIE subunit beta (291 aa, $~ 33 \mathrm{kDa}$ ) is encoded by the human GTF2E2 gene. This protein is involved in the mediation of both transcriptional initiation and RNA elongation. 